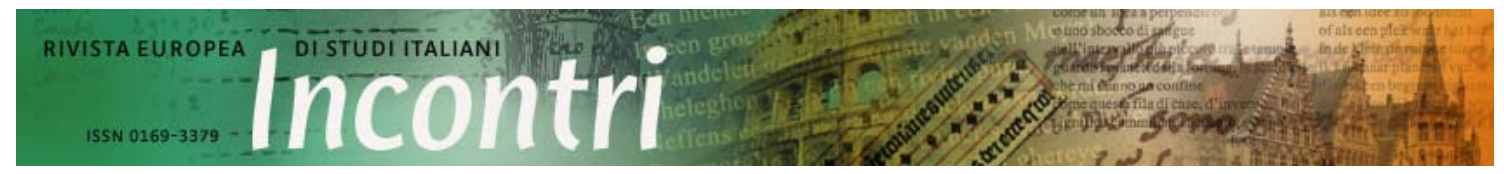

Anno 34, 2019 / Fascicolo 1 / p. 122-127 - www.rivista-incontri.nl - http://doi.org/10.18352/incontri.10290 (C) The author(s) - Content is licensed under a Creative Commons Attribution 3.0 Unported License Publisher: Werkgroep Italië Studies, supported by Utrecht University Library Open Access Journals

\title{
Dante and the beatitudes: moral transformation in Purgatorio
}

\section{Anton ten Klooster}

In Dante's Purgatorio, after a deadly sin has been purged, an angel proclaims one of the beatitudes, or sayings Jesus had given at the beginning of the Sermon on the Mount (Mt. 5, 3-9). ${ }^{1}$ However, in the Divina Commedia it is not immediately clear what the interrelatedness of sin, virtue, grace and beatitudes is. This essay presents Dante's use of these so-called evangelical beatitudes as a key theological motive of Purgatorio. Through his formation in Florence Dante was familiar with the works of both Thomas Aquinas and Bonaventure. With them he shares a preoccupation with happiness as the final end or goal of human life. Dante's dependence on these theologians can explain the seemingly peculiar presence of the beatitudes in Purgatorio. In this essay we will first address how the beatitudes are a structural element of Purgatorio, and which theological sources may have inspired their use. This allows us to address the relation between each beatitude and the sin that has been purged. Together, these insights lead to the conclusion that in Purgatorio the beatitudes are markers of the process of moral transformation.

\section{Dante as a student of theology}

Dante Alighieri shared with the theologians of the thirteenth century a preoccupation with the quest for happiness as the ultimate end for human beings. His Divina Commedia can be considered a 'poem of ends', that is of the ends of human life: death, judgment, heaven and hell. ${ }^{2}$ Human life is a journey, the famous 'cammin di nostra vita' of the first canto of the Commedia, and its end is the same as that of the comedy: the vision of God in paradise. Purgatorio resembles the journey of the human wayfarer. Both in hell and heaven respectively, the damned and blessed have already arrived at their final destination; the souls in purgatory, on the contrary, are still on their way toward it. They must cast off sin in order to eventually become "pure and disposed to ascend to the stars' (Pg. 33, 145). The theologians of the thirteenth century also spoke of life as a journey to God. One of the most famous examples is Bonaventure's Itinerarium mentis in Deum. Thomas Aquinas, the other towering figure of medieval theology, abandoned the theological handbooks of his time to begin work in his Summa Theol ogiae which was intended to end with a discussion of the last things (death, judgment, heaven and hell), but his death prevented him from finishing it. Aquinas and Bonaventure are the first theologians to speak in the Commedia and this is no coincidence. After Beatrice's death, Dante sought consolation in philosophy by

\footnotetext{
1 There is also a version of the beatitudes in Luke 6, 20-23. The medieval theologians followed Augustine in making the beatitudes in Matthew the cornerstone of their interpretation.

${ }^{2}$ A.N. Williams, 'The Theology of the Comedy', in: R. Jacoff (ed.), The Cambridge Companion to Dante, Cambridge, Cambridge University Press, 2007 (second edition), p. 201.
} 
going to the 'schools of the religious and the disputations of the philosophers', as he mentions in the Convivio (II, xxii, 7). He is referring to the schools of the Dominicans at Santa Maria Novella and the Franciscans at Santa Croce, where he familiarised himself with Bonaventure's Itinerarium and Aquinas' Summa. ${ }^{3}$ Dante's studies at the schools provided him with the broad knowledge of Scripture, liturgy, theology and philosophy that we witness in the Commedia. ${ }^{4}$

This essay discusses how the beatitudes are used in the structure of Purgatorio. When we reflect on the theological use of the beatitudes by Aquinas in particular we can begin to understand why Dante used them in his work. Secondary literature on the Commedia does mention the beatitudes, but often only in passing. Introductions to the structure of Purgatorio present its rings, the vices and the penances performed for them, the virtues opposing the vices, but more often than not the beatitudes are excluded altogether from these reflections. It seems that the interpretation of Dante suffers from the same flaw as the study of medieval theology, namely that it considers the beatitudes as ornamental elements of a discourse whereas they are fundamental to understanding the theological or literary discussion of the journey of human life, in keeping with a long theological tradition that considers the Sermon on the Mount the ultimate standard of Christian morality.

Purgatorio is laden with citations from Scripture, more so than any other book of the Commedia. Scripture is after all the book of the wayfarer: the damned in hell are no longer able to benefit from it, while the blessed in heaven no longer require it in order to know and love God. Throughout Purgatorio, by contrast, the recurrence of the beatitudes is constant. This sermon is a sustained ethical reflection. The beatitudes function as a sort of prologue, with a repeated proclamation of 'blessed', aimed at different groups of people. Dante follows the theological custom of reading them as series of seven rather than counting Matthew 5, 10 as the eighth beatitude. For those who read the Bible in Latin, as Dante most likely did, the repeated use of beati triggers an association with the eternal beatitudo which is the end of human life. This is reinforced by the promise of heaven that concludes the first beatitude: 'blessed are the poor in spirit, for theirs is the kingdom of heaven'. In Purgatorio these beatitudes are counterposed to the vices, resounding in each of the rings after Dante the traveller has passed through a particular domain of vice. Although it may be true that we should 'be cautious to attribute to Dante any sustained textual reflection on the Sermon on the Mount in and for itself', his repeated use of the beatitudes and the fact that he studied at Dominican and Franciscan houses begs the question how he saw the beatitudes. ${ }^{5}$ Should they be interpreted as antidotes to sin and do they describe the itinerarium toward God, following Bonaventure? ${ }^{6}$ Or should they be read in Thomist fashion as the right moral actions of the converted believer? Either way, medieval commentators were all familiar with Augustine's monumental commentary on the sermon introducing the notion of gradus, different steps along the way toward the perfection of the Christian life. ${ }^{7}$ This is the notion Dante takes up when he incorporates the beatitudes in his literary construction of the seven rings of purgatory.

\footnotetext{
${ }^{3}$ R.W.B. Lewis, Dante Alighieri, New York, Viking Penguin Group, 2001, p. 65.

${ }^{4}$ Cfr. V. Montemaggi, Reading Dante's Commedia as Theology: Divinity Realized in Human Encounter, Oxford, Oxford University Press, 2016, p. 105.

${ }^{5}$ D.L. Jeffrey, 'Dante and Chaucher', in: J.P. Greenman, T. Lars, \& S.R. Spencer (eds.), The Sermon on the Mount Through the Centuries: From the Early Church to J ohn Paul II, Grand Rapids, Brazos Press, 2007, p. 83.

6 J.T. Schnapp, 'Introduction to Purgatorio', in: Jacoff (ed.), The Cambridge Companion to Dante, cit., p. 98; Jeffrey, 'Dante and Chaucher', cit., pp. 83-84.

${ }^{7}$ Lansing suggests a reliance on Hugh of St. Victor's De Quinque Septenis. Given the heavy influence of Franciscan and Dominican theology on Dante, and the relative lack of interest in Hugh by Bonaventure
} 


\section{The beatitudes in the structure of Purgatorio}

Whenever a capital sin has been overcome in Purgatorio one of the beatitudes is proclaimed, beginning with 'blessed are the poor in spirit', quoted in Latin. Each beatitude marks a transition of one ring to the next as the travellers leave behind a particular domain of sin. We hear the first beatitude in Purgatorio 12, 109-111 after passing through the domain of the prideful: 'Noi volgendo ivi le nostre persone / Beati pauperes spiritu! Voci / cantaron sì, che nol diria sermone'. In the first two rings Dante only hears a voice, in the higher rings he begins to see and feel feathers and wings. It is only in the seventh ring that he explicitly speaks of 'an angel of God' (Pg. 27, 6): 'Fuor de la fiamma stava in su la riva, / e cantava Beati mundo corde! / in voce assi più che la nostra viva' (Pg. 27, 7-9). The beatitudes accompany his journey to paradise and are proclaimed by a heavenly messenger, whose identity becomes clear as the traveller is purged of his sins and comes closer to heaven.

There are some peculiarities in Dante's use of the beatitudes. He does not include all seven of them, in spite of there being seven rings in purgatory. Instead, he omits the beatitude of the meek and divides the beatitude of those who hunger and thirst for justice in two. ${ }^{8}$ The poet also rearranges their order. Only the first beatitude is in its place in the Biblical order whereas all the others are placed throughout the rings. The key to Dante's arrangement of the beatitudes can be found by reading beyond the first part of each beatitude. The word 'blessed' stands at the beginning of each beatitude but they all end differently with the promise of a particular blessing. For example, the seventh beatitude calls the peacemakers 'blessed' and contains the promise that they shall be called 'children of God'. But Dante places the beatitude of the clean of heart at the highest place. He only quotes the opening words of the verse but any medieval reader will know the promises attached to it: 'they will see God'. This indeed is the end or purpose of the entire comedy and life itself, to attain the eternal bliss of seeing God. Even though Dante does not take up the Biblical and traditional order of the beatitudes, he does incorporate them in the Commedia as a motive of purification. Those who are purged of a particular sin are called beati, blessed. When reading these parts of Purgatorio in light of the insights of medieval theology we can see the relation between the sin that is purged and the beatitude chosen by the poet.

'Blessed are the poor in spirit' we hear when the sin of pride has been purged. Dante the traveller feels that he has cast off a burden and remarks to his guide Virgil that the journey is now less exhausting. The guide notes in response that the first of the seven ' $P$ ' written on Dante's forehead has been erased. Pride features in the first ring, since it is considered 'the root of all sin' following Ecclesiasticus 10, 15 in the Latin Vulgate. ${ }^{9}$ It is the root of sin because it is the first of all sins. Adam and Eve were proud because they assumed they could be like God, many medieval commentators argued. ${ }^{10}$ Humility and fear of God are the traits attributed by Augustine to the 'poor

and Aquinas a reliance on that particular work would seem less likely. R. Lansing, 'Beatitudes', in: idem (ed.), The Dante Encyclopedia, London, Routledge, 2010, p. 89.

${ }^{8}$ Cfr. Jeffrey, 'Dante and Chaucer', cit., p. 87. I respectfully disagree with Jeffrey's estimation that this beatitude 'unambiguously has to do with this world rather than eternal reward'; there are several examples of a spiritual interpretation of "earth" in this particular context. Still, the association may be what led Dante to forego using this beatitude.

9 C.S. Singleton, The Divine Comedy of Dante Alighieri: Translated, with a Commentary, vol. 2.2, Purgatorio - Commentary, Princeton, Princeton University Press, 1977, p. 266.

10 See for instance: F.R. Larcher (translation), J. Mortensen \& E. Alarcón (eds.), Thomas Aquinas, Commentary on the Letter of Saint Paul to the Romans, Lander, Aquinas Institute for the Study of Sacred Doctrine, 2012, cap. 5, lectio 5, nr. 446, p. 151. 
in spirit'. ${ }^{11}$ It is therefore fitting that pride is the first sin purged and that it is aligned with this particular beatitude.

Envy is the capital sin purged in the second ring and it is aligned with the words 'blessed are the merciful' (Pg. 15, 38). Mercy is the opposite of envy. Thomas Aquinas takes up an earlier definition of mercy as having 'a miserable heart for the misery of others'. ${ }^{12}$ To be merciful is to will the good for another whereas envy seeks to seize the goods of another. The sin of wrath is aligned with the beatitude of the peacemakers (Pg. 17, 68-69). Wrath disrupts the order of things by repaying evil with evil, but those who establish peace restore the tranquil order willed by the Creator. In the fourth ring the souls in purgatory must overcome acedia, or sloth. This is the middle part of the journey through purgatory. In light of the Christian ascetic tradition it is fitting to place acedia in the middle. Around noon monks would grow weary of their mortification and were tempted to fall asleep, the so-called 'noonday devil'. ${ }^{13}$ Similarly, those in purgatory must continue their burdensome journey, in this particular instance of contrapasso through the penance of running. Before proceeding to the ring of the greedy the travellers hear the words 'blessed are they who mourn' (Pg. 19, 50). Augustine interprets this mourning as part of the process of conversion. Those who follow Christ leave behind the life of sin and everything attached to it, and this causes them to mourn for the life they leave behind. ${ }^{14}$ This includes leaving behind spiritual sloth and following Christ with fervour. The sins of avarice and gluttony are connected to two parts of the beatitude 'blessed are they who hunger and thirst for justice'. Those who thirsted for possessions are called blessed when their desires have been purged: 'e quei c'hanno a giustizia lor disiro / detto n'avea beati, e le sue voci / con sitiunt, sanz'altro, ciò forniro' (Pg. 22, 4-6). With typical irony Dante speaks of righteous hunger for the gluttons: blessed are they who hunger not for food but for righteousness (Pg. 24, 154). This is the only instance where he does not quote the Vulgate but refers to the beatitudes in the vernacular, connecting them explicitly to the illuminating grace of God: 'Beati cui alluma tanto di grazia' (Pg. 24, 151-152). Finally, once the sin of lust has been overcome the angel sings 'Beati mundo corde', blessed are the clean of heart (Pg. 27, 7-9). Dante follows major traditions of interpretation and takes this as a reference to chastity.

\section{The moral transformation of the wayfarer}

The beatitudes thus accompany the journey through purgatory. This in itself is noteworthy: the virtues in themselves are not sufficient to overcome vice. The reflection on virtues originates in philosophy and it is first of all a reflection on human efforts. But human efforts alone are not enough to reach paradise. Socrates, Plato and Aristotle were virtuous men but they are in limbo because they did not receive grace. Dante's use of the beatitudes emphasises that the journey of the human wayfarer needs to be informed by revelation as well. One could argue, as some interpreters do, that the beatitudes are antidotes to $\sin .{ }^{15}$ The fact that the first ' $P$ ' has disappeared after the first beatitude seems to support this. But each beatitude is proclaimed after a particular domain of sin, that is when that sin has become a thing of the past. This suggests that the beatitudes mark the life of the purified believer. In this

\footnotetext{
11 A. Mutzenberger (ed.), Augustine, De Sermone Domini in Monte Libros Duos, Corpus Christianorum Series Latina 35, Turnhout, Brepols, 1967, I, 1,3, p. 4.

12 A.M. Ten Klooster, Thomas Aquinas on the Beatitudes: Reading Matthew, Disputing Grace and Virtue, Preaching Happiness, Leuven, Peeters, 2018, pp. 108, 284.

${ }^{13}$ For a succinct explanation see: K. Kennedy, 'Before Sloth Meant Laziness, It Was the Spiritual Sin of Acedia', Atlas Obscura, https://www.atlasobscura.com/articles/desert-fathers-sins-acedia-sloth (July 14 2017).

14 Ten Klooster, Thomas Aquinas on the Beatitudes, cit., p. 105.

${ }^{15}$ Cfr. Schnapp, 'Introduction to Purgatorio', cit., p. 98.
} 
interpretation the happiness of heaven gradually begins to take shape in purgatory. The aforementioned gradual revelation of an angel would follow the same logic. These things explain why one on the way to paradise is already called 'blessed' by a heavenly messenger. The heavenly reward is still beyond the vision of the wayfarer, but eternal bliss already presents itself a rudimentary state.

Our reading of Purgatorio takes us to a major disagreement between Bonaventure and Aquinas with regard to the beatitudes. Even though Dante did not study the Sermon on the Mount in great detail, he was aware of the importance of the beatitudes to the spirituality of the mendicants and the theological debates of the time. Bonaventure held that the beatitudes were habits, dispositions proper to the life of the Christian. ${ }^{16}$ Aquinas on the other hand defined them as acts. Both of them follow the Aristotelian distinction between habit and act, that is between the disposition to act present within a person and the act itself. The underlying theological question is what leads a person to act virtuously. Aquinas holds that God infuses habits - virtues - in the human soul that allow that person to act accordingly. The beatitudes then help us to understand what actions are proper to the Christian life. Bonaventure believed that the beatitudes were the habits, and that they are dispositions to right action rather than actions themselves. To Aquinas the beatitudes describe the virtuous actions of the Christian who is transformed by the grace of God. ${ }^{17}$ The question is whether the beatitudes help the believer in his struggle with sin, or if they describe the actions of a believer who has already overcome certain sins. Either way, there will be a struggle with sin, since even those predestined for heaven will suffer the effects of sin. In the theology of Thomas Aquinas the beatitudes describe actions that spring forth from grace, and in that sense they refer to a situation where sin has already lost at least some of its grip on a person. In this way the placement of the beatitudes mirrors that of the exempla given in purgatory, which also precede the overcoming of sins. ${ }^{18}$ By placing the beatitudes at the transition from one ring to the next Dante seems to follow this interpretation. Both for the poet and the theologian the beatitudes designate progress on the way toward happiness. This progress is made possible by the grace of God, something Aquinas discusses extensively in his Summa Theologiae and that Dante mentions in Purgatorio 24: 'beati cui alluma tanto di grazia'. It is because the beatitudes describe features of the redeemed person that the seventh beatitude in canto 27 is followed shortly by Christ's invitation to the elect. From a radiant light this call resounds: 'Venite benedicti Patris mei, / sonò dentro a un lume che lì era, / tal che mi vinse e guardar nol potei' (Pg. 27, 58-60).

Dante connects the beatitudes to vices and virtues. Rereading Purgatorio in light of significant theological interpretations of the beatitudes suggests that Dante's choice to incorporate them in the narrative structure of the work is an effort to place the human struggle with sin and weakness in light of its ultimate goal: happiness in God. Their use evokes the notion of God actively drawing the elect toward Him, something expressed most explicitly in the gospel of John: 'No one can come to me unless the Father who sent me draw him' (John 6, 44), a verse that features frequently in Aquinas' discussions of grace. Without seeking to impose Christian orthodoxy on Dante, this approach suggests new ways of reading the progress of Dante the traveller. This in turn helps us to think of new ways to speak of the moral transformation of the wayfarer on whose journey the poet reflects in Purgatorio.

\footnotetext{
${ }^{16}$ For a summary of medieval theories on the beatitudes and the gifts and virtues related to them see: 0 . Lottin, 'Les Dons du Saint-Esprit chez les Théologiens depuis P. Lombard jusqu'à S. Thomas d'Aquin', in: Recherches de Théologie Ancienne et Médiévale, 1 (1929), pp. 41-61.

${ }_{17} \mathrm{Cfr}$. Ten Klooster, Thomas Aquinas on the Beatitudes, cit.

18 This interpretation was a felicitous suggestion from an anonymous reviewer of this journal.
} 


\section{Keywords}

Divina Commedia, medieval theology, beatitudes, Thomas Aquinas, Bonaventure

Anton ten Klooster is Assistant Professor of theology at Tilburg University. In 2018 he successfully defended his dissertation Thomas Aquinas on the Beatitudes: Reading Matthew, Disputing Grace and Virtue, Preaching Happiness. At Tilburg, he initiated and co-taught a course on Dante's Purgatorio.

Tilburg University

School of Catholic Theology

PO Box 80101 - 3508 TC

Utrecht (The Netherlands)

a.m.tenklooster@uvt.nl

\section{RIASSUNTO}

\section{Dante e le beatitudini: trasformazione morale nel Purgatorio}

Questo saggio presenta i riferimenti alle beatitudini evangeliche (Mt 5, 3-9) da parte di Dante come chiave di lettura per comprendere il motivo teologico del Purgatorio. Dopo la purgazione di un peccato mortale, un angelo proclama una beatitudine. Nella Divina Commedia, però, non è immediatamente chiaro quale sia la correlazione tra peccato, virtù, grazia e beatitudini. Dante conosceva le idee teologiche di Tommaso d'Aquino e di Bonaventura, e come loro esprimeva una preoccupazione per la felicità come fine ultimo dell'individuo umano. La sua dipendenza da questi teologi può spiegare la presenza delle beatitudini nel Purgatorio. In questo saggio si discutono le beatitudini come elemento strutturale per Dante, nonché le fonti teologiche a cui esse risalgono, al fine di capire meglio la relazione tra le beatitudini e i peccati purificati. Cosi, vediamo che le beatitudini preludono già, seppure in forma rudimentale, alla partecipazione alle cose celesti da parte dell'individuo umano. 